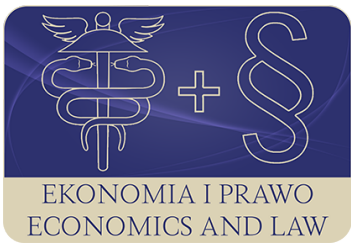

EKONOMIA I PRAWO. ECONOMICS AND LAW

Volume 19, Issue 2, June 2020

p-ISSN 1898-2255, e-ISSN 2392-1625

www.economicsandlaw.pl

EKONOMIA I PRAWO

ORIGINAL ARTICLE

received 11.11.2019; revised 10.01.2020; accepted 30.06.2020

Citation: Zdunek-Rosa, E., Huterska, A., Łapińska, J., \& Huterski, R. (2020). Assessment of the company's financial condition using a synthetic measure based on the example of a confectionery company. Ekonomia i Prawo. Economics and Law, 19(2): 379-391. doi:10.12775/EiP.2020.026.

\title{
Assessment of the company's financial condition using a synthetic measure based on the example of a confectionery company
}

\section{EWA ZDUNEK-ROSA}

Nicolaus Copernicus University in Torun, Faculty of Economic Sciences and Management,

Department of Econometrics and Statistics, Poland

$\square$ ezdunek@umk.pl

(D) orcid.org/0000-0002-6858-7309

\section{AGNIESZKA HUTERSKA}

corresponding author

Nicolaus Copernicus University in Torun, Faculty of Economic Sciences and Management,

Department of Digital Economy and Finance, ul. Gagarina 13a, 87-100 Toruń, Poland

๑ huterska@umk.pl

(D) orcid.org/0000-0002-4722-2853

JUSTYNA EAPIŃSKA

Nicolaus Copernicus University in Torun, Faculty of Economic Sciences and Management,

Department of Organizational Behavior and Marketing, Poland

๑ justlap@umk.pl

(iD) orcid.org/0000-0003-4134-4750

\section{ROBERT HUTERSKI}

Nicolaus Copernicus University in Torun, Faculty of Economic Sciences and Management,

Department of Digital Economy and Finance, Poland

๑ robhuski@umk.pl

orcid.org/0000-0001-9821-7176 


\begin{abstract}
Motivation: Many methodological problems are associated with measuring and forecasting the company's financial standing. Various methods have been developed to assess the current and future financial standing of enterprises. Their usefulness requires development and verification based on the example of a specific enterprise. The evaluation of one of these methods is the subject of this article.

Aim: The research objective of the article is to propose a method for assessing the financial situation of a company and to carry out a forecast of the financial condition of an economic entity based on this method. To analyse the condition, indicator analysis and one of the methods of multivariate comparative analysis (MCA) were used — a synthetic measure was constructed, and then the time series analysis method was used (the model of the internal structure of the examined process was estimated). The study also attempts to determine the company's financial condition forecast. The results of the study were presented based on the example of a company representing the food industry the Wawel SA company.

Results: In this study, the financial condition of the company was presented using a synthetic measure, which is a tool for multivariate comparative analysis (MCA). A model of the internal structure of the examined process was also estimated, based on which a forecast of the financial condition of a selected company representing the food industry was determined. The analysis showed that the presented methods are very useful for assessing and forecasting the company's financial condition.
\end{abstract}

Keywords: financial condition; complex phenomenon; synthetic measure; zero unitarization method (ZUM); time series model

JEL: C32; C51; C53

\title{
1. Introduction
}

Functioning in a market economy requires that enterprises should constantly verify and evaluate their results. Analytical information, including those regarding the financial condition, not only allows efficient and effective day-to-day management of the entity, but also serves to make the right strategic decisions facilitating the development of the company in the future. They are also important for the company's stakeholders, in particular for current and potential investors (Pieloch-Babiarz, 2017; Pietrzak et.al. 2017).

A preliminary analysis of the company's basic financial statements, i.e. the balance sheet, profit and loss account and cash flow statement, only allows a simplified assessment of the financial condition of the audited entity. A thorough examination of the economic and financial condition requires in-depth analyses, including a comparison of the results achieved by the audited entity with the results achieved by competitors in the industry, as well as the reference of the results achieved by the entity to sector values. An important element of the economic and financial analysis of enterprises is also taking into account non-financial information related to the functioning of the entity under scrutiny. Tools that allow assessing the financial condition of enterprises, using financial indicators calculated on the basis of financial statements, include 
methods used to predict the threat of bankruptcy (Gissel at al., 2007; Hardle et al., 2011; Sandin \& Porporato, 2008). They include such elements of financial assessment as financial liquidity, operational efficiency (efficiency of use of assets), level of debt, or profitability. These methods have their advantages, but they are also not free from disadvantages.

The research objective of the article is to propose a method for assessing the financial situation of an enterprise based on the construction of a synthetic measure and to make a forecast of the financial condition of a selected economic entity based on the results of this method.

\section{The financial condition of the company as a complex phenomenon: literature review}

Complex phenomena are phenomena described by at least two features that can have different titers and orders of magnitude. These phenomena are the subject of research of multidimensional comparative analysis (MCA), which is also called statistical comparative analysis (SCA) or multidimensional statistical analysis (MSA). Multidimensional methods that allow to analyse complex phenomena are used in many fields, including macro- and microeconomics, marketing, finance and banking, ecology, education, tourism, medicine, demography and many more (Kukuła, 2000; Rogalska, 2018; Zopounidis \& Doumpos, 2002).

An example of a complex phenomenon in finance is the company's financial condition. The assessment of the financial condition of a given entity consists of the assessment of various areas of the company's operations, such as financial liquidity, operational efficiency (efficiency of use of assets), debt or profitability. Ratio analysis, using financial ratios calculated on the basis of financial statements, allows to assess each of these areas separately. Therefore, it is advisable to search for methods that would allow assessing the financial condition of the company in a holistic way Sierpińska (2004). In the literature on the subject there are many methods for assessing the economic and financial situation of a company. An overview of methods, see, for example Siemińska (2002). These methods include discriminant analysis, logit or probit analysis, artificial neural networks, survival analysis. Examples of applications are presented in the works of (Hasanaj \& Kuqi, 2019; Huterska \& Zdunek-Rosa, 2016; Łapińska et al. 2018; Zdunek-Rosa \& Huterska, 2018).

Enterprises operating in a market economy must permanently verify and evaluate their results. The collected analytical data - including those regarding the financial condition - allow for efficient day-to-day management of the enterprise as well as making the right strategic decisions having a significant impact on the company's future functioning. This information is also extremely important from the point of view of the company's stakeholders, including current and potential investors (Kotane \& Kuzmina-Merlino, 2012). 


\section{Methods}

The article uses the values of financial indicators describing the financial situation of the Wawel SA company in the time period from the first quarter of 2007 to the first quarter of 2019 (a total of 49 quarterly data). The data come from the Biznes radar (2019) website.

In this study, index analysis and one of the methods of multivariate comparative analysis (MCA) were used to assess and forecast the financial condition of the company - a synthetic measure was constructed, and then the model of the internal structure of the examined process was estimated.

Multidimensional comparative analysis (MCA) methods are used also for the purpose of analysing the dynamics of complex phenomena. The concept of a complex phenomenon is closely related to the concept of diagnostic variable and synthetic (aggregate) variable. Diagnostic variables are variables describing the studied complex phenomenon, while the synthetic variable is 'a variable which, based on a set of standardized diagnostic variables, quantitatively determines the level (the degree of development) of the considered phenomenon in the examined subjects'. The synthetic measure is a quantity without titers and takes values in the range [0;1] (Kukuta, 2000, p. 21). As part of the multidimensional comparative analysis (MCA), hierarchy methods (linear ordering methods, dendrite ordering, tree hierarchy methods), grouping methods (direct methods, iterative methods), selection methods, discrimination methods (Dimitruk \& Gawiniecki, 2017).

In order to normalize the value of individual financial ratios, the zero unitarization method (ZUM) was applied. The method is based on the following formula that evaluates stimulants (Kukuła, 2000):

$$
Z_{i j}=\frac{x_{i j}-\min _{i} x_{i j}}{\max _{i} X_{i j}-\min _{i} x_{i j}} \text {, for } \max _{i} x_{i j} \neq \min _{i} x_{i j} \text {. }
$$

In the case of destimulants, the normalizing formula is given by the formula below:

$$
Z_{i j}=\frac{\max _{i} x_{i j}-X_{i j}}{\max _{i} X_{i j}-\min _{i} X_{i j}}, X_{j} \in D .
$$

The formula transforming a neutral variable into a stimulant takes the form:

$$
Z_{i j}=\left\{\begin{array}{l}
\frac{x_{i j}-\min _{i} x_{i j}}{c_{o j}-\min _{i} x_{i j}} \text { for } x_{i j} \leq c_{o j} \\
\frac{x_{i j}-\max _{i} x_{i j}}{c_{o j}-\max _{i} X_{i j}} \text { for } x_{i j}>c_{o j}
\end{array},\right.
$$


where $c_{0 j}$ is the nominal value of the variable $X_{j}$.

In the case of neutral variables with a range of nominal values $\left[c_{1 j} ; c_{2 j}\right]$, the normative formula is given by the formula:

$$
Z_{i j}=\left\{\begin{array}{ll}
\frac{x_{i j}-\min _{i} x_{i j}}{c_{l j}-\min _{i} x_{i j}} & \text { for } x_{i j}<c_{l j} \\
1 \quad \text { for } c_{l j} \leq X_{i j} \leq c_{2 j} \\
\frac{X_{i j}-\max _{i} X_{i j}}{c_{2 j}-\max _{i} x_{i j}} & \text { for } x_{i j}>c_{2 j}
\end{array} .\right.
$$

The normalized variable $z_{i j}$ always takes a value from the range $[0 ; 1]$.

Next, a synthetic variable describing the financial condition of the Wawel SA company in individual quarters of the audited period was constructed. The following formula aggregating normalized diagnostic variables has been used in the article (Kukuła, 2000):

$$
Q_{i}=\frac{l}{k} \sum_{j=1}^{k} Z_{i j},
$$

for $i=1,2, \ldots, n$. This formula assumes the same importance of all diagnostic features describing the studied complex phenomenon.

Then, an attempt was made to estimate the structure model describing the changes in the condition of the Wawel SA company during the period considered. Based on the model, a forecast of the condition of the audited company was determined for the second, third and fourth quarters of 2019.

\section{Results}

Fifteen financial indicators were adopted to examine the economic situation of Wawel SA, characterizing four main areas of the company's activity, i.e., liquidity, debt, profitability, and operational efficiency. These indicators are a set of potential diagnostic variables. The list of diagnostic variables along with the description of their nature (i.e., impact on the company's financial position) is contained in table 1.

Potential diagnostic variables were analysed for the degree of differentiation and correlation between individual variables. To assess the degree of variation in the variables, the coefficient of variation and the relative amplitude of fluctuations were calculated (Kukuła, 2000). As a result, an indicator characterizing the sustainability of the financing structure was excluded and finally 14 other financial indicators were used to construct the synthetic measure.

After determining the nature of individual diagnostic variables (see table 1), their values were normalized. Out of the many standardization methods, the zero unitarization method has been chosen as one that meets all of the con- 
ditions required for this type of method (Kukuła, 2000). In addition to bringing the values of various variables to comparability, this method also allows the unification of the nature of the variables (i.e., it allows the conversion of destimulants and neutral variables into stimulants). In the last stage of the synthetic variable construction, normalized variables were aggregated and the synthetic measure values for individual quarters of the analysed period were calculated.

Chart 1 presents the dynamics of the financial condition - represented by the synthetic measure - of Wawel SA in the subsequent quarters of the period under review. The values of the synthetic variable are normalized in the range $[0 ; 1]$. The closer the value of this variable is to unity, the higher the level of the complex phenomenon (here: the financial condition of the company is better).

In the examined period, the synthetic measure took values in the range [0.353; 0.692]. Wawel SA had the worst financial situation in the last period, i.e., the first quarter of 2019, while the best one, in turn, was recorded in the first period, i.e., in the first quarter of 2007. The analysis of changes in the condition of the company audited in the recent period shows following the fourth quarter of 2017 the company's condition was deteriorating.

In the further part of the study, an attempt was made to estimate the model describing the condition of Wawel SA in the period from the first quarter of 2007 to the first quarter of 2019. For this purpose, the model of the internal structure of the examined process was estimated (Osińska, 2007, p. 146). In the proposed model, the explained process is the financial condition of Wawel SA $\left(K F_{t}\right)$. Then the internal structure of the analysed process was examined, i.e., the occurrence of the trend, quarterly seasonality and autoregression was checked (Kufel, 2007). The study showed that the model describing changes in the condition of Wawel SA should include a linear trend and autoregression from the 5th order. The model hypothesis can be written as follows:

$$
K F_{t}=\alpha_{0}+\alpha_{1} t+\alpha_{2} K F_{t-1}+\alpha_{3} K F_{t-2}+\alpha_{4} K F_{t-3}+\alpha_{5} K F_{t-4}+\alpha_{6} K F_{t-5}+\varepsilon_{t} \text {. }
$$

Structural parameters of the above model were estimated using the classical least-squares method.

Table 2 presents the results of the estimation of the model describing the financial condition of Wawel SA before the posteriori elimination and table 3 after the elimination of insignificant explanatory variables (based on the Student's t-test).

The estimated form of the trend-autoregressive model is as follows:

$$
\hat{K} F_{t}=0.2916-0.0016 t+0.5134 K F_{t-1}+0.3372 K F_{t-4}-0.3250 K F_{t-5} \text {. }
$$

Then the model was verified. The above model is statistically correct. All structural parameters of the model are statistically significant. The coefficient $R^{2}=0.5493$, which means that $54.83 \%$ of the total variability of the financial condition of the company audited was explained by the model. The level of explanation of the variability of financial condition by the model is there- 
fore not very high. The coefficient of random variation $V_{e}=7.86 \%$ informs that $7.86 \%$ of the average value of the synthetic measure is a standard error of residuals. Assuming that the limit value of the random coefficient of variation is $10 \%\left(V^{*}=10 \%\right)$, it can be assumed that the deviations of the empirical values of Wawel SA's condition from the theoretical values are small. This means that the model is well suited to empirical data (see chart 2).

Based on the indications of partial autocorrelation function (PACF), it can be concluded that the rest of the model have white-noise properties (see chart 3). The absolute values of partial autocorrelation coefficients for subsequent time delays are significantly lower than the limit value of 0.2955 .

Such properties of the random component distribution as homogeneity of variance of random component and normality of random component distribution were also assessed. In addition, the correctness of model specification and stability over time of model parameters were examined. Table 4 presents the results of the respective statistical tests. In each case, there is no reason to reject the null hypothesis $\left(H_{0}\right)$, with the adopted significance level of 0.05 $(\alpha=0.05)$. Therefore, it can be assumed that the variance of the random component is homogeneous (the random component is homoscedastic), the random component has a normal distribution, the model specification is correct and the structural parameters of the model are stable over time. The model is therefore statistically acceptable.

The model can be used in practice, e.g., to estimate financial condition forecasts. Table 5 presents forecasts for the condition of the Wawel SA company for the second, third and fourth quarters of 2019, together with ex ante prediction errors.

Assuming that the prediction error limit is $15 \%$, all forecasts can be considered acceptable, i.e., sufficiently accurate from the perspective of the user's forecast needs. The estimated forecasts for the next three quarters of 2019 show that the financial condition of the audited company will gradually improve from quarter to quarter.

\section{Conclusion}

The company's financial condition can be treated as a complex phenomenon. It is described by variables characterizing the four main areas of the company's activity: liquidity, profitability, operational efficiency and debt. Indicator analysis, based on past data and using a large number of financial indicators, can ambiguously describe the financial condition of an enterprise (Redel, 2003). The conclusions drawn from the analysis of individual indicators may even be contradictory. For this reason, the use of index analysis tools for assessing the financial situation of an enterprise must be 'properly balanced and supplemented with other analytical tools'.

In this study, the financial condition of the company was presented using a synthetic measure, which is a tool for multidimensional comparative analysis 
(MCA). A model of the internal structure of the examined process was also estimated, based on which a forecast of the financial condition of a selected company representing the food industry was determined. The analysis showed that the presented methods are very useful for assessing and forecasting the company's financial condition.

\section{References}

Biznes radar. (2019). Retrieved 11.11.2019 from https://www.biznesradar.pl.

Dimitruk, J., \& Gawiniecki, J. (2017). Metody wielowymiarowej analizy porównawczej: budowa i zastosowanie. Biuletyn Wojskowej Akademii Technicznej, 66(4). doi:10.5604/01.3001.0010.8224.

Gissel, J., Giacomino, D., \& Akers, M. (2007). A review of bankruptcy prediction studies: 1930-present. Journal of Financial Education, 33.

Hardle, W.K., Hoffmann, L., \& Moro, R. (2011). Learning machines supporting bankruptcy prediction. In P. Cizek, W.K. Hardle, \& R. Weron (Eds.), Statistical tools for finance and insurance. Berlin: Springer. doi:10.1007/978-3-642-18062-0_7.

Hasanaj, P., \& Kuqi, B. (2019). Analysis of financial statements. Humanities and Social Science Research, 2(2). doi:10.30560/hssr.v2n2p17.

Huterska, A., \& Zdunek-Rosa, E. (2016). Zastosowanie modelu probitowego oraz uciętego liniowego modelu prawdopodobieństwa do analizy kondycji ekonomiczno-finansowej wybranych przedsiębiorstw z indeksu mWIG40. Zeszyty Naukowe Uniwersytetu Szczecinskiego: Finanse, Rynki Finansowe, Ubezpieczenia, 83(5). doi:10.18276/frfu.2016.5.83/2-11.

Kotane, I., Kuzmina-Merlino, I. (2012), Assessment of financial indicators for evaluation of business performance. European Integration Studies, 6. doi:10.5755/j01.eis.0.6.1554.

Kufel, T. (2007). Ekonometria: rozwiązywanie problemów z wykorzystaniem programu Gretl. Warszawa: PWN.

Kukuła, K. (2000). Metoda unitaryzacji zerowanej. Warszawa: PWN.

Łapińska, J., Zdunek-Rosa, E., Huterska, A., Kądzielawski, G., \& Łapiński, P. (2018). Ocena kondycji finansowej polskich przedsiębiorstw przemysłu chemicznego. Przemyst Chemiczny, 1(8). doi:10.15199/62.2018.8.4.

Osińska, M. (2007). Prognozowanie na podstawie jednorównaniowego modelu ekonometrycznego. In M. Osińska (Ed.), Ekonometria wspótczesna. Toruń: TNOiK.

Pieloch-Babiarz, A. (2017). Determinants of payout policy and investment attractiveness of companies listed on the Warsaw Stock Exchange. Equilibrium. Quarterly Journal of Economics and Economic Policy, 12(4). doi:10.24136/ eq.vl2i4.35. 
Pietrzak, M.B., Fałdziński, M., Balcerzak, A.P., Meluzin, T., \& Zinecker, M. (2017). Short-term shocks and long-term relationships of interdependencies among Central European capital markets. Economics \& Sociology, 10(1). doi:10.14254/2071-789x.2017/10-1/5.

Redel, D. (2003). Wykorzystanie sprawozdawczości finansowej do celów analitycznych. In L. Szyszko, \& J. Szczepański (Eds.), Finanse przedsiębiorstwa. Warszawa: PWE.

Rogalska, E. (2018). Multiple-criteria analysis of regional entrepreneurship conditions in Poland. Equilibrium. Quarterly Journal of Economics and Economic Policy, 13(4). doi:10.24136/eq.2018.034.

Sandin, A.R., \& Porporato, M. (2008). Corporate bankruptcy prediction models applied to emerging economies: evidence from Argentina in the years 1991-1998. International Journal of Commerce and Management, 17(4) doi:10.1108/10569210710844372.

Siemińska, E. (2002). Metody pomiaru i oceny kondycji finansowej przedsiębiorstwa. Toruń: UMK.

Sierpińska, M. (2004). Wskaźnikowa ocena kondycji finansowej przedsiębiorstwa. In M. Sierpińska, \& T. Jachna (Eds.), Ocena przedsiębiorstwa wedtug standardów światowych. Warszawa: PWN.

Zdunek-Rosa, E., \& Huterska, A. (2018). Zastosowanie modeli upadłości przedsiębiorstw do oceny kondycji ekonomiczno-finansowej wybranych przedsiębiorstw z indeksu WIG-Spożywczy. Studia i Prace Wydziału Nauk Ekonomicznych iZarządzania Uniwersytetu Szczecińskiego, 3(54). doi:10.18276/ sip.2018.54/3-29.

Zopounidis, C., \& Doumpos, M. (2002). Multi-criteria decision aid in financial decision making: methodologies and literature review. Journal of Multi-Criteria Decision Analysis, 11(4-5). doi:10.1002/mcda.333.

\section{Acknowledgements}

Author contributions: authors have given an approval to the final version of the article. Authors contributed to this work as follows: E.Z-R., A.H., J.E., R.H. developed the concept and designed the study, E.Z-R., A.H., J.E., collected the data, E.Z-R., A.H., R.H. analysed and interpreted the data, E.Z-R., A.H., J.E., R.H. prepared draft of article, E.Z-R., A.H., J.E., R.H. revised the article critically for important intellectual content.

Funding: this research was funded by the authors' own resources. 


\section{Appendix}

Table 1.

Potential diagnostic variables

\begin{tabular}{ccc}
\hline Indicator category & Indicator name & The nature of the diagnostic variable \\
\hline \multirow{2}{*}{ profitability } & ROE & stimulant \\
& ROA & stimulant \\
& operating profit margin & stimulant \\
net profit margin & stimulant \\
debt & general debt & destimulant \\
& equity debt & destimulant \\
long-term debt & destimulant \\
sustainability of the financing structure & stimulant \\
\hline fixed assets coverage ratio & stimulant \\
current ratio & quick ratio & neutral variable $\left(1.2-2.0^{*}\right)$ \\
copherational efficiency & neutral variable $\left(1.0^{*}\right)$ \\
& cycle of receivables & neutral variable $\left(0.2^{*}\right)$ \\
\hline
\end{tabular}

Notes:

* denotes the nominal value (or a range of nominal values) of the diagnostic variable, i.e., the value (a range of values) of the variable for which the level of the complex phenomenon is the highest.

Source: Own preparation. 
Table 2.

Results of the estimation of the structure model before a posteriori elimination

\begin{tabular}{|c|c|c|c|c|}
\hline \multirow{2}{*}{ Independent variables } & \multicolumn{4}{|c|}{ Dependent variable $\left(K F_{t}\right)$} \\
\hline & Coefficient & Standard error & Student's t-statistics & $\mathrm{p}$-value \\
\hline const & 0.2879 & 0.1207 & 2.3860 & $0.0223^{* *}$ \\
\hline time & -0.0016 & 0.0006 & -2.5740 & $0.0142^{* *}$ \\
\hline$K F_{t-1}$ & 0.4907 & 0.1653 & 2.9680 & $0.0052^{* * *}$ \\
\hline$K F_{t-2}$ & 0.1039 & 0.1633 & 0.6366 & 0.5283 \\
\hline$K F_{t-3}$ & -0.0985 & 0.1615 & -0.6095 & 0.5459 \\
\hline$K F_{t-4}$ & 0.3630 & 0.1499 & 2.4220 & $0.0205^{* *}$ \\
\hline$K F_{t-5}$ & -0.3284 & 0.1378 & -2.3830 & $0.0224^{* *}$ \\
\hline \multicolumn{3}{|l|}{ observations } & 44 & \\
\hline \multicolumn{3}{|l|}{ standard error of residuals } & 0.0418 & \\
\hline \multicolumn{3}{|l|}{ determination coefficient $R^{2}$} & 0.5551 & \\
\hline \multicolumn{3}{|l|}{$\mathrm{F}(6.37)$} & 7.6941 & \\
\hline \multicolumn{3}{|c|}{$\mathrm{p}$-value for the F-test } & 0.0000 & \\
\hline \multicolumn{3}{|c|}{ random variation coefficient $V_{e}$ (in \%) } & 8.01 & \\
\hline \multicolumn{3}{|c|}{ limit value of the random variation coefficient $V^{*}$ (in \%) } & 10.00 & \\
\hline
\end{tabular}

Notes:

${ }^{*}$ statistically significant variable at the level of $10 \%$; ${ }^{* *}$ statistically significant variable at the level of $5 \%$; *** statistically significant variable at the level of $1 \%$.

Source: Own preparation.

Table 3.

Results of estimation of the structure model after a posteriori elimination

\begin{tabular}{|c|c|c|c|c|}
\hline \multirow{2}{*}{ Independent variables } & \multicolumn{4}{|c|}{ Dependent variable $\left(K F_{t}\right)$} \\
\hline & Coefficient & Standard error & Student's t-statistics & $\mathrm{p}$-value \\
\hline const & 0.2916 & 0.1058 & 2.7560 & $0.0089^{* * *}$ \\
\hline time & -0.0016 & 0.0006 & -2.7180 & $0.0097^{* * *}$ \\
\hline$K F_{t-1}$ & 0.5134 & 0.1455 & 3.5280 & $0.0011^{* * *}$ \\
\hline$K F_{t-4}$ & 0.3372 & 0.1366 & 2.4660 & $0.0182^{* *}$ \\
\hline$K F_{t-5}$ & -0.3250 & 0.1328 & -2.4480 & $0.0190^{* *}$ \\
\hline \multicolumn{3}{|l|}{ observations } & 44 & \\
\hline \multicolumn{3}{|l|}{ standard error of residuals } & 0.0410 & \\
\hline \multicolumn{3}{|l|}{ determination coefficient $R^{2}$} & 0.5483 & \\
\hline \multicolumn{3}{|l|}{$\mathrm{F}(4.39)$} & 11.8359 & \\
\hline \multicolumn{3}{|l|}{$\mathrm{p}$-value for the F-test } & 0.0000 & \\
\hline \multicolumn{3}{|c|}{ random variation coefficient $V_{e}$ (in \%) } & 7.86 & \\
\hline \multicolumn{3}{|c|}{ limit value of the random variation coefficient $V^{*}$ (in \%) } & 10.00 & \\
\hline
\end{tabular}

Notes:

* statistically significant variable at the level of $10 \%$; ** statistically significant variable at the level of $5 \%$; *** statistically significant variable at the level of $1 \%$.

Source: Own preparation. 
Table 4.

Results of statistical tests

\begin{tabular}{lccc}
\hline \multicolumn{1}{c}{ Statistical test } & Null hypothesis $\left(H_{0}\right)$ & Test statistics & $\mathrm{p}$-value \\
\hline White's test & random component is homoscedastic & $\mathrm{LM}=12.2949$ & 0.5826 \\
Doornik-Hansen test & random component has normal distribution & $\chi^{2}(2)=1.8893$ & 0.3888 \\
Reset test & correct specification & $\mathrm{F}(2,37)=1.2934$ & 0.2865 \\
Cusum test & structural parameters of the model are stable over time & $\mathrm{t}(38)=-1.8408$ & 0.0735 \\
\hline
\end{tabular}

Source: Own preparation.

Table 5.

Forecasted values of the financial condition of the Wawel SA company for the second, third and fourth quarters of 2019 and ex ante errors

\begin{tabular}{lccc}
\hline Forecast period $(T)$ & Forecast $\left(y_{T p}\right)$ & Average prediction error $\left(\delta_{T}\right)$ & Relative average prediction error $\left(\delta_{T}{ }^{*}\right)($ in $\%)$ \\
\hline $2019: 2$ & 0.3920 & 0.0410 & 10.47 \\
$2019: 3$ & 0.3942 & 0.0461 & 11.70 \\
$2019: 4$ & 0.4141 & 0.0474 & 11.44 \\
\hline
\end{tabular}

Source: Own preparation.

\section{Chart 1.}

The values of the synthetic variable for Wawel SA covering the period from the first quarter of 2007 to the first quarter of 2019

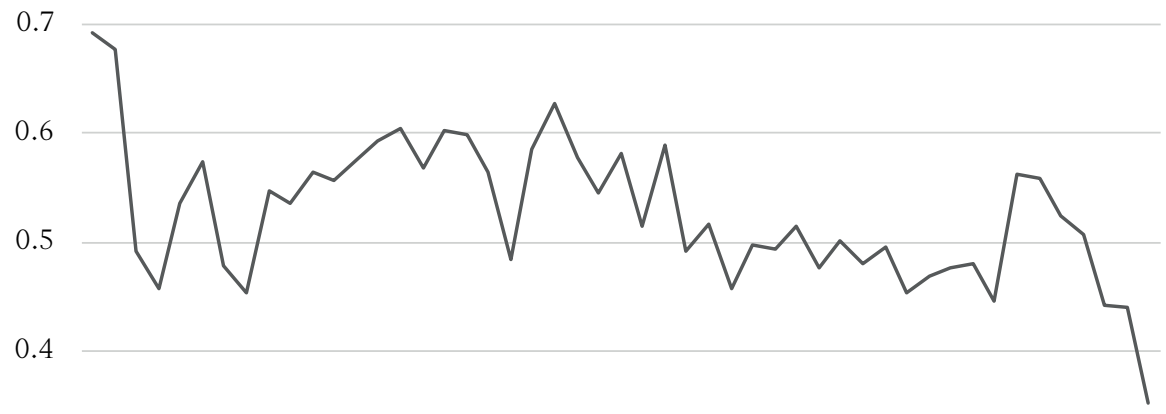

0.3

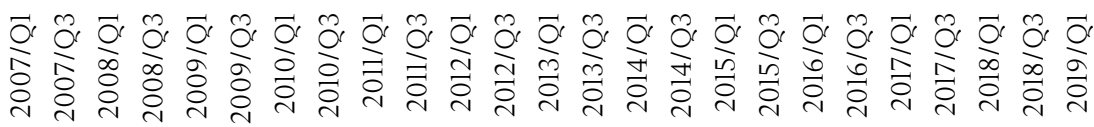

Source: Own preparation. 
Chart 2.

Empirical and theoretical values of the financial condition of Wawel SA actual and fitted financial condition

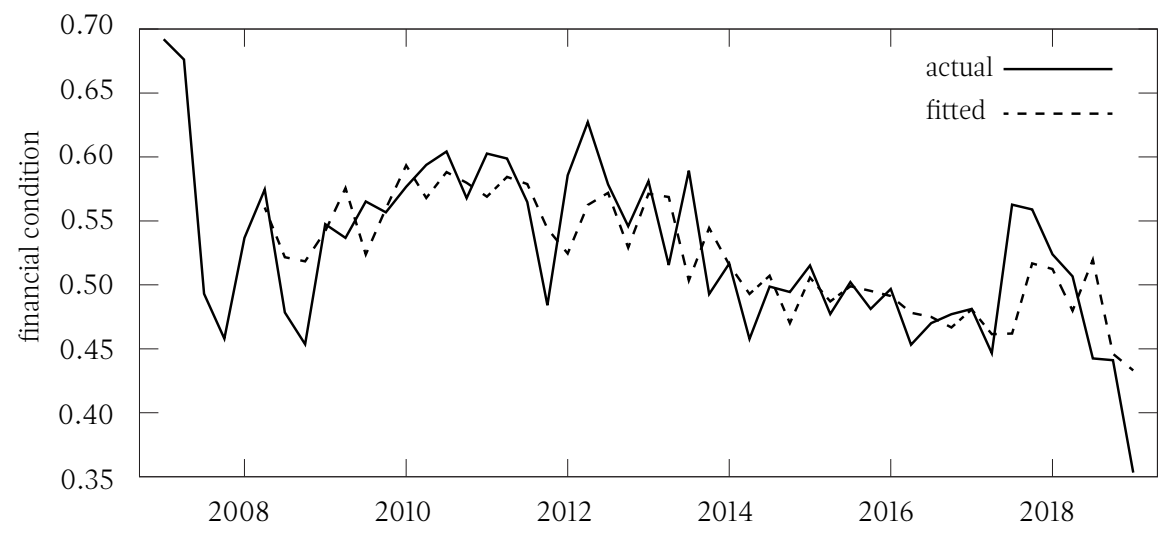

Source: Own preparation.

Chart 3.

Partial autocorrelation function (PACF) values

residual PACF

$+-1.96 / \mathrm{T}^{\wedge} 0,5$

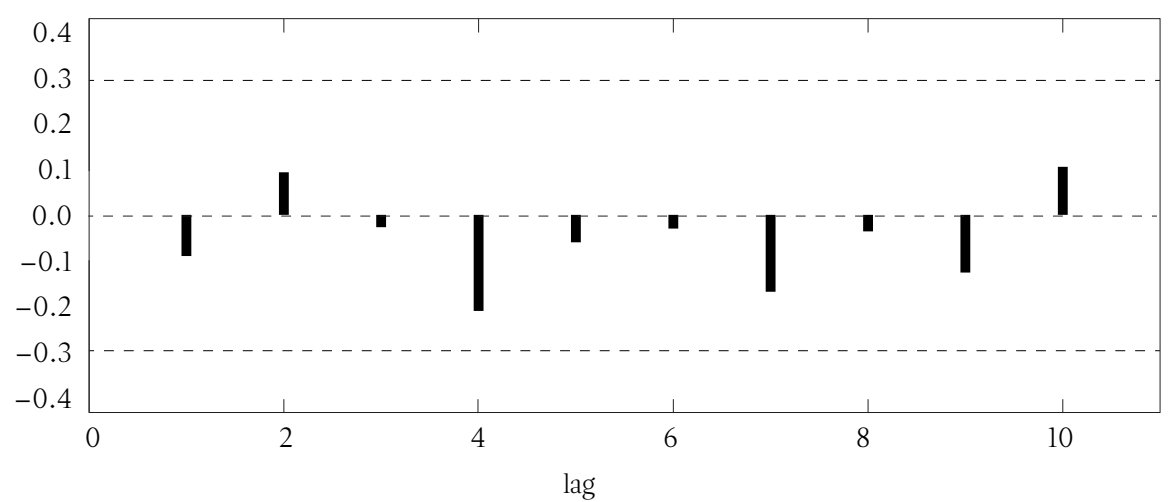

Source: Own preparation. 
